\title{
Milk Producer Companies in India: A Review
}

\author{
Devesh Thakur* \\ Department of Veterinary and Animal Husbandry Extension Education, CSK Himachal \\ Pradesh Agricultural University, Palampur, Himachal Pradesh, India \\ *Corresponding author
}

\section{A B S T R A C T}

\begin{tabular}{l} 
Ke y w o r d s \\
Constraints in \\
Livestock \\
production, Dairy \\
Farmer Interest \\
Groups, Milk \\
Producer Company, \\
NDDB \\
\hline Article Info \\
\hline $\begin{array}{l}\text { Accepted: } \\
\text { 12 October } 2020 \\
\text { Available Online: } \\
\text { 10 November } 2020\end{array}$ \\
\hline
\end{tabular}

\begin{abstract}
Livestock farming is livelihood source to millions of small, marginal and landless farmers in India. These farmers face numerous challenges in livestock feeding, poor animal health care, weak extension services, poor credit mechanisms and improper milk marketing. Many of these challenges can be solved by organizing farmers into collective action. Cooperatives as means to collectivize dairy farming have made limited success in India. Therefore, alternative institutional mechanisms for farmer collectivization are needed. Milk producer companies as hybrid of dairy co-operatives and business companies are an emerging concept. Experiences of many milk producer companies suggest that members benefit from improved delivery of input mechanisms and also have better access to milk marketing. Milk producers are able to receive quality inputs at lower prices, provision of artificial insemination and veterinary services improves, extension advisory services are more regular and milk marketing improves considerably. The empirical reviews on functioning and operations of milk producer companies are lacking under Indian context. The present article would be useful for grass root dairy development organizations to orient their activities in this direction.
\end{abstract}

\section{Introduction}

Livestock production in India is dominated by marginal, small and landless farmers. Huge number (100 million) of small holder farmers in India contributes to $90 \%$ of livestock production (Leitch et al., 2014). These marginal and small farmers contribute to $73 \%$ of total milk production in India (Kumar et al., 2018). Such farmers face innumerable constraints: lack of quality feed and fodder, high cost of inputs, weak extension support, lack of timely veterinary services and lower prices of milk (Kumar and Parappurathu, 2014). On the other hand, the institutions dealing with these smallholder farmers also face challenges; smaller scale of operations of these farmers, scattered locations, underdeveloped infrastructure to access them, involvement of multiple intermediaries and low marketable surplus (Trebbins and Hassler, 2012; Satyasai and Mehrotra, 2016) .Collective action of the farmers can minimize most of these problems. Farmer producer organizations are recognized instruments of collective action in India (Kujur et al., 2019). 
Producer Organization is a generic name that represents various cooperatives, self help groups (SHG's), federation of SHGs, commodity interest groups, farmers Club and producer company etc. (Pustovoitova, 2011) These organizations aim to improve farmers' accessibility to credit, inputs and markets (Chander and Sulaiman, 2014 and Jose et al., 2019). Among all these organizations, producer companies have find fervor in agricultural sector across India.

Dairy co-operatives as means to collectivize milk production and processing have made limited success in India. Restrictive cooperative laws prevented co-operatives from becoming autonomous business entities (Singh, 2019). Bureaucratic control, elite capture, political entrenchment and corruption have marred the efficiency of dairy cooperatives (Bhandari, 2010; Bhattacharjee, 2010).

Co-operatives need more freedom to operate as business entities in competitive market. Alternative design of producer institutions was required to make co-operatives more likely to succeed (Singh and Singh, 2013).So Indian Companies Act, 1956 was amended in 2003 and concept of producer company came into existence (Alagh, 2007). A Producer company is the hybrid between a private limited company and a co-operative society. It combines benefits of professional management of former and welfare consideration of the latter (NABARD, 2015).

\section{Difference between dairy co-operative and dairy producer company}

A producer company has done away with the features which affected the efficiency of cooperatives. The differences apply for dairy cooperative and dairy producer company and are mentioned in table 1.

\section{Status of Milk Producer Companies (MPCs) in India}

The foremost dairy company registered in India is Vijaya Visakha Milk Producers Company Telangana, which initially was known as Visakha Dairy union in the year 2006 (Sood, 2015). National dairy Development Board (NDDB) spearheaded the formation of dairy producer companies in regions where cooperatives were not present or had low coverage and procurement (Singh, 2019). It began organizing milk producer into milk producing institutions in year 2005 in Saurashtra-Kutch region. Such milk producing institutions gradually evolved as milk producer companies (NDDB, 2020). The initial dairy producer companies established by NDDB were Payas and Maahi in 2012 (Singh, 2019).

At present 210 active milk producer companies exist in India; 81 percent of them are less than 5 years old; 50 percent of top 20 farmer producer companies are dairy based (Neti et al., 2019). Some of India's large milk producer companies Maahi (Guajarat), Paayas (Rajasthan), Saahaj (UP), Baani (Punjab) and Sreeja (AP) have been supported by NDDB (Shah, 2016). More than half of the active MPCs are in just four states: Maharashtra, Rajasthan, Madhya Pradesh and Uttar Pradesh (Govil et al., 2020) (Table 2).

Unlike other farmer based producer companies, MPCs tend to have large number of farmer shareholders. Also, many MPCs have been converted from older dairy cooperatives with significant membership and capital. Furthermore, even new dairies find it relatively easier to ramp up their membership and operations quickly because the dairy sector has a well-established blueprint for collectivization, procurement, processing and sales (Neti et al., 2019). 
Benefits offered by milk producer companies

Most of the bigger MPCs procure and process milk. They offer balanced cattle feed, specific mineral mixture, ration balancing, quality fodder seed and timely credit to farmers. Several MPCs have initiated doorstep artificial insemination delivery. They also organize several extension training programme such as producer awareness, women awareness, rural youth awareness program and rural school children program. The Shreeja all women milk producer company uses animated PPT module and pico-projectors to make extension education activities more interesting to the farmers.

The extension education activities involve producer awareness program in which benefits of becoming milk members and procedure of becoming members of MPC are explained. The program provides importance of quality and clean milk production, factors affecting quality of milk (including breeding and feeding practices). Similarly youth are encouraged to undertake dairying as profession and become members of MPC. Besides rural leadership program and school children program are some other extension education activities undertaken.

\section{Formation of milk producer company}

Formation of milk producer company initially requires formation of smaller farmer interest groups engaged in milk production. This group of 10-20 producers frames and follow certain rules; regular meeting, saving, training etc. The group selects two representatives and requires external support by nongovernmental organization or state development department. Once viable groups are formed (25 number), minimum share capital (Rs 1000) is collected by the members to form a milk producer company. Few selected members from individual farmer interest groups would be part of board of the company. Further out of these, few members will act as board of directors of the company. NABARD /SFAC official of the concerned region support registration of the company

\section{Formation of a milk producer company requires following steps}

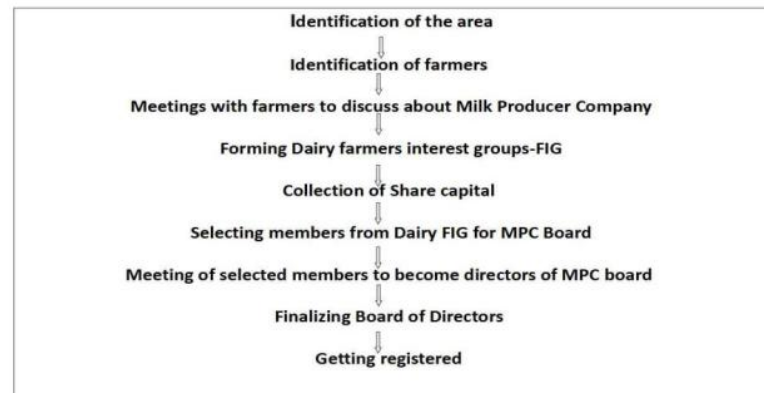

\section{Dairy based Farmer Interest Groups (FIG) can undertake following activities}

Each dairy based FIG assesses the required cattle inputs such as feed, feed additives by farmers. This information is shared with the FPO and feed is made available to milk producers

It should collect share capital from the members and hand over the money to Milk Producer Company

FIG can collect savings from the members and disburse loan to its members and ensure repayments from its members.

Maintain books of accounts and ensure updating and auditing of books of accounts annually with assistance from the Milk Producer Company

\section{Functions of milk producer company}

\section{Input supply to farmers}

One of the initial functions which MPC can take up is ensuring supply of feed, fodder and other inputs to farmers. 
Initially company should opt for bulk buying of feed and fodder seeds for its members. The farmers will benefited by lower feed prices, inputs at doorsteps and better quality.

The margin from the cattle feed business can be used to meet its various operational costs (Jose and Meena, 2019).

\section{Milk procurement}

Milk producer company can up milk pooling points in villages and engage in milk procurement and processing. Use of electronic milk testing facility, GIS and other ICT tools ensures transparency in its operation (Payas, 2019).

Table.1 Difference between co-operatives and producer company

\begin{tabular}{|c|c|c|}
\hline Parameters & Co-operatives & Producer Company \\
\hline Registration & Cooperative Societies Act & Indian Companies Act \\
\hline $\begin{array}{l}\text { Area of } \\
\text { Operation }\end{array}$ & Registered operational area & $\begin{array}{l}\text { No restriction if permitted in Ministry of } \\
\text { Agriculture }\end{array}$ \\
\hline \multirow{2}{*}{$\begin{array}{l}\text { Nature of } \\
\text { Business }\end{array}$} & Marketing, service and delivery & Primarily agencies to provide marketing \\
\hline & agencies & solutions to pooled produce \\
\hline Membership & $\begin{array}{l}\text { Based on ownership of land } \\
\text { /residence }\end{array}$ & Based on concept of shareholding \\
\hline Share & Non-transferable & $\begin{array}{l}\text { Transferable to active members as decided by } \\
\text { board }\end{array}$ \\
\hline Profit sharing & Limited dividends on shares & Commensurate with volume of business \\
\hline \multirow{3}{*}{ Voting rights } & One member, one vote & One member, one vote. Members \\
\hline & Government and Registrar of & not having transactions with \\
\hline & Cooperatives hold veto power & company cannot vote \\
\hline \multirow[t]{6}{*}{ Governance } & Federated into the District & Stand-alone, self-reliant \\
\hline & Cooperative Union/ Regional & bodies with self-governing \\
\hline & cooperative Union & Capabilities \\
\hline & Receive financial, & \\
\hline & technical and administrative & \\
\hline & support from the government & \\
\hline Reserves & Created if there are profits & Mandatory \\
\hline \multirow{4}{*}{$\begin{array}{l}\text { Borrowing } \\
\text { Power }\end{array}$} & Restricted to loans granted and & More freedom and more \\
\hline & disbursed by the co-operative & alternatives available. FPCs are \\
\hline & bank to which the PAC is linked & allowed to raise capital from \\
\hline & & external sources \\
\hline $\begin{array}{l}\text { Relationship } \\
\text { with }\end{array}$ & Transaction based & Producers and corporate/non-profit \\
\hline $\begin{array}{l}\text { other business } \\
\text { and }\end{array}$ & & entities can together float a \\
\hline $\begin{array}{l}\text { non-profit } \\
\text { entities }\end{array}$ & & Producer Company \\
\hline
\end{tabular}

Source: SFAC, 2013 
Table.2 Prominent milk producer companies in India

\begin{tabular}{|c|c|c|c|c|}
\hline & $\begin{array}{l}\text { Name of Milk Producer } \\
\text { Company }\end{array}$ & $\begin{array}{l}\text { Year of } \\
\text { registration }\end{array}$ & $\begin{array}{l}\text { Area of } \\
\text { operation }\end{array}$ & Salient features \\
\hline & $\begin{array}{l}\text { Sri Vijaya Visakha Milk } \\
\text { Producer Company }\end{array}$ & 2006 & $\begin{array}{l}\text { Andhra } \\
\text { Pradesh }\end{array}$ & $\begin{array}{l}\text { Earlier as Vaishaka dairy co-operative and got } \\
\text { converted into Milk Producer Company. } \\
\text { 2.Fastest growing Milk and Milk Products } \\
\text { Manufacturing Company with turnover of } \\
\text { Rs.1000 at CAGR of Rs } 14 \%\end{array}$ \\
\hline & $\begin{array}{l}\text { Payas Milk Producer } \\
\text { Company }\end{array}$ & 2012 & Rajasthan & $\begin{array}{l}\text { Supported by NDDB } \\
\text { Milk procurement from } 3526 \text { villages with daily } \\
\text { milk procurement of } 8.57 \text { lakh litres per day. }\end{array}$ \\
\hline & $\begin{array}{l}\text { Maahi Milk Producer } \\
\text { Company }\end{array}$ & 2012 & Gujarat & $\begin{array}{l}\text { Supported by NDDB } \\
\text { Milk procurement of } 8.12 \text { lakh litres per day with } \\
1,11,967 \text { members }\end{array}$ \\
\hline & $\begin{array}{l}\text { Sahaj Milk Producer } \\
\text { Company }\end{array}$ & 2014 & Uttar Pradesh & $\begin{array}{l}\text { Supported by NDDB } \\
\text { Milk procurement of } 5.94 \text { lakh litres per day with } \\
\text { more than } 80,000 \text { members }\end{array}$ \\
\hline 5. & $\begin{array}{l}\text { Karimnagar Milk Producer } \\
\text { Company }\end{array}$ & 2012 & Telangana & $\begin{array}{l}\text { Average procurement per day is } 1.5 \text { lakh litres } \\
\text { from } 70,000 \text { milk producer members }\end{array}$ \\
\hline & $\begin{array}{l}\text { Maval Dairy Farmer Services } \\
\text { Producer Company Ltd }\end{array}$ & 2019 & $\begin{array}{l}\text { Pune, } \\
\text { Maharastra }\end{array}$ & $\begin{array}{l}\text { Supported by Tata Power } \\
\text { Maharashtra's first all-women milk producer } \\
\text { company }\end{array}$ \\
\hline & $\begin{array}{l}\text { Sakhi Mahila Milk Producer } \\
\text { Company }\end{array}$ & 2016 & $\begin{array}{l}\text { Mewat region, } \\
\text { Rajasthan }\end{array}$ & $\begin{array}{l}\text { Supported by TATA Trust } \\
1,10,000 \text { liters of milk per day from more than } \\
18,000 \text { active women share holder members }\end{array}$ \\
\hline
\end{tabular}

Sources: Gupta, 2019; Neti et al., 2019; Agriculture today, 2020; Singh, 2019

Table.3 Challenges of dairy farmers and possible remedial measures through milk producer companies

\begin{tabular}{|l|l|l|}
\hline $\begin{array}{l}\text { Problems in Livestock } \\
\text { sector }\end{array}$ & $\begin{array}{l}\text { Challenges as Individual } \\
\text { Farmer }\end{array}$ & $\begin{array}{l}\text { Possible interventions through Milk } \\
\text { Producer companies }\end{array}$ \\
\hline $\begin{array}{l}\text { I Livestock feeding problems } \\
\text { i) Unaffordable cattle feed } \\
\text { cost }\end{array}$ & $\begin{array}{l}\text { Lower input requirement } \\
\text { limits bargaining power, } \\
\text { presence of intermediaries } \\
\text { results in higher cost of feed. } \\
\text { Discretion in selection of } \\
\text { feed and other inputs is } \\
\text { minimal }\end{array}$ & $\begin{array}{l}\text { Farmer producer company takes up feed } \\
\text { selling activity and buys in bulk. } \\
\text { Experiences suggestive that price of feedand } \\
\text { inputs decreases and individual discretion to } \\
\text { choose feed and inputs increases. } \\
\text { Bigger companies can establish their own feed } \\
\text { units }\end{array}$ \\
\hline ii)Shortage of green fodder & $\begin{array}{l}\text { Non availability of land for } \\
\text { fodder production by } \\
\text { marginal and smallholder } \\
\text { livestock producers }\end{array}$ & $\begin{array}{l}\text { MPC/FIGs can make use of community lands } \\
\text { by tying up through local organization for } \\
\text { green fodder cultivation }\end{array}$ \\
\hline $\begin{array}{l}\text { iii)Shortage of dry fodder } \\
\text { (wheat, rice straw/stubble }\end{array}$ & $\begin{array}{l}\text { Majority of livestock owners } \\
\text { have minimal landholdings }\end{array}$ & $\begin{array}{l}\text { Farmers organized as farmer interest groups } \\
\text { under Milk Producer Company can directly }\end{array}$ \\
\hline
\end{tabular}




\begin{tabular}{|c|c|c|}
\hline and other crop residues) & $\begin{array}{l}\text { and do not have enough dry } \\
\text { fodder. Landholding farmers } \\
\text { possess crop residues. But } \\
\text { lack sufficient labor to collect } \\
\text { and transport dry fodder. } \\
\text { Livestock producers buy dry } \\
\text { fodder at high costs (Rs 6-12) } \\
\text { per kg. (NITI Aayog,2018) }\end{array}$ & $\begin{array}{l}\text { contact landholding farmers and collect, } \\
\text { transport and store dry fodder. This will } \\
\text { increase availability, reduce wastage and cost } \\
\text { of dry fodder to dairy farmers }\end{array}$ \\
\hline \multicolumn{3}{|l|}{ II. Poor Health care } \\
\hline $\begin{array}{l}\text { Unavailability of timely } \\
\text { Veterinary services. }\end{array}$ & $\begin{array}{l}\text { The veterinary services is } \\
\text { largely a public sector domain } \\
\text { and there is shortage of } 40- \\
50 \% \text { trained manpower (Rao } \\
\text { et al., 2015). } \\
\text { The farmers are dependent on } \\
\text { government machinery for } \\
\text { veterinary services which } \\
\text { does not differentiate in } \\
\text { quality and non quality } \\
\text { livestock. }\end{array}$ & $\begin{array}{l}\text { Milk producer companies can hire veterinary } \\
\text { services on user charge basis. This will bring } \\
\text { more employment opportunities for the trained } \\
\text { manpower in the sector and improve } \\
\text { availability as per quality of animal. }\end{array}$ \\
\hline $\begin{array}{l}\text { Non availability of } \\
\text { Artificial Insemination (AI) } \\
\text { services }\end{array}$ & $\begin{array}{l}\text { AI coverage is still } 26 \% \text { of } \\
\text { the breed able population. } \\
\text { The number of AI performed } \\
\text { per day is } 1.92 \text { as against the } \\
\text { required average of at least } 4 \\
\text { per day (GOI, 2017) }\end{array}$ & $\begin{array}{l}\text { Many leading producer companies have } \\
\text { initiated pilot model of AI delivery (Payas } \\
\text { MPC, 2019). } \\
\text { Govt. of India has allowed Milk Producer } \\
\text { Companies (FPO) to establish multipurpose } \\
\text { AI technicians in Rural India after necessary } \\
\text { approval (GOI, 2020). This enables increased } \\
\text { AI coverage through MPCs }\end{array}$ \\
\hline \multicolumn{3}{|c|}{ III Poor Extension and Credit mechanisms } \\
\hline $\begin{array}{l}\text { Weak dairy information } \\
\text { support resulting in poor } \\
\text { awareness about animal } \\
\text { health practices }\end{array}$ & $\begin{array}{l}\text { Transaction cost to reach } \\
\text { individual farmer is high } \\
\text { Sporadic extension activities. } \\
\text { Lack of communication skills }\end{array}$ & $\begin{array}{l}\text { Farmers in MPCs have extension linkages } \\
\text { with various actors in dairy value chain } \\
\text { (Vishnu and Gupta, 2017). } \\
\text { MPCs using innovative extension mechanism } \\
\text { such as model dairy farms, use of digital and } \\
\text { ICT tools for members. }\end{array}$ \\
\hline Poor credit availability & $\begin{array}{l}\text { Institutions do not lend credit } \\
\text { due to resource poor nature } \\
\text { Many dairy farmers are } \\
\text { women who lack collateral to } \\
\text { seek loan }\end{array}$ & $\begin{array}{l}\text { Savings and credit facility offered by many } \\
\text { MPCs } \\
\text { Women MPCs can help to overcome this } \\
\text { problem of lack of collateral . }\end{array}$ \\
\hline \multicolumn{3}{|c|}{ IV Milk marketing related constraints } \\
\hline $\begin{array}{l}\text { 1.Non remunerative milk } \\
\text { price } \\
\text { 2.Difficulty in } \\
\text { transportation } \\
\text { 3.Poor bargaining power }\end{array}$ & $\begin{array}{l}\text { Milk has poor shelf life } \\
\text { Intermediaries take up share } \\
\text { of price } \\
\text { Individual farmers have } \\
\text { limited resources to preserve } \\
\text { and process milk. }\end{array}$ & $\begin{array}{l}\text { Direct milk marketing as company undertakes } \\
\text { milk procurement from farmers } \\
\text { This enables dairy producers to save in terms } \\
\text { of time, transaction costs, forced sales, price } \\
\text { fluctuations, transportation and quality } \\
\text { maintenance. }\end{array}$ \\
\hline
\end{tabular}




\section{Marketing}

Dairy producer companies are positioned better for sale of milk and milk products. Milk transport and storage services can be offered to farmers through milk pooling. Thus, improved milk quality, packaging and branding is possible through milk producer companies (Shreeja MPC, 2018).

\section{Veterinary services}

The dairy company can ensure delivery of artificial insemination and veterinary services through hired veterinarian and para-veterinary staff. Government of India has recently allowed farmer producer companies to establish multipurpose AI technicians in Rural India after necessary approval (GOI, 2020). This enables increased AI coverage through MPCs to the farmers.

\section{Social security services}

Dairy producer companies offer loans, savings to the farmers (Jose and Meena, 2019). Vijaya Visakha Milk Producer Company extends medical services to farmers and their families at subsidized rates. It offers education to the farmers' children, preference to producers' children in employment, irrigation projects, bridges, canals etc. (Rao, 2019).

\section{Challenges of dairy farmers and possible remedial measures through milk producer companies}

NITI Aayog (2018), Sreeram et al.(2018), Singh et al., (2015) and Subburaj et al., (2015) have discussed various challenges faced by farmers in India. Table 3 explains how farmers as members of milk producer companies can overcome these problems than individually.
In conclusion the small scale dairy farmers face numerous challenges in animal feeding, health care, extension \& milk marketing constraints. Many of these problems can be overcome by milk producer companies.

The concept of MPCs is gaining prominence in India. Government of India has fixed a target of 10,000 farmer producer organisations by 2023-24 (GOI, 2020). This may mean setting up of several milk producing companies in India by earmarked cluster based organisations.

The state departments of animal husbandry, ICAR institutes, agricultural and veterinary universities, KVKs and dairy development organizations have huge role in formation and support to Milk Producer Companies.

They need to reorient their activities in the changing circumstances, to retain their societal relevance. Evidences are suggestive of milk producer companies helping farmers to reap benefits of market linkages and technological innovations.

\section{References}

Aayog, N.I.T.I. 2018. Demand and supply projections towards 2033 crops, livestock, fisheries and agricultural inputs, The working group report, Govt. of India, New Delhi.

Agriculture Today. 2020. India Dairy Awards, the national agriculture magazine, 22(2):3640

Alagh, K.Y. 2007. On Producer Companies. PRADHAN'S workshop on producer companies. DOI http://www.pradan.net/ images/news/prof_ykalagh.pdf (accessed 1.5.20)

Bhandari, V. 2010. India in transition. Organizational forms in flux: Cooperatives and producer companies, Center for the Advanced Study of India and the Trustees of the University of Pennsylvania. DOI http://casi.ssc.upenn. 
edu/iit/bhandari (accessed 21.5.20).

Bhattacharjee, S. 2010. Experience of producer organizations: A case of five producer companies. Financing Agric., 42(7): 1221

Chander, M. and Sulaiman, R.V. 2014. Strengthening extension and advisory services through producer organizations: A case of milk producer cooperatives in India, proceedings and recommendations of the consultations on the role of producer organization in strengthening extension and advisory provision in the Dairy/Livestock Sector in India, (AugustOctober, 2014)

GOI. 2017. State wise Target set for 100 million Artificial Insemination for 2017-18. Press Information Bureau, Government of India Ministry of Agriculture and Farmers Welfare. DOI: https://pib.gov.in/ newsite/PrintRelease. aspx? relid=169770( accessed 25.4.20)

GOI.2020.Establishment of Multipurpose AI Technicians in Rural India (MAITRIS), epashuhatt, Department of Animal Husbandry and Dairying ,Ministry of Fisheries, Animal Husbandry and Dairying, GOI, DOI :https://epashuhaat.gov.in/?module=p_ma rketplaceandaction=maitri

GOI.2020. Formation and Promotion of 10,000 Farmer Producer Organizations (FPOs) Scheme 2020 Scheme Guidelines Department of Agriculture, Co-operation \& Farmers' Welfare Ministry of Agriculture \& Farmers' Welfare, Government of India.

Govil, R., Neti, A., and Madhushree, R.R. 2020. Farmer producer companies: Past, present and future. Azim Premji University, Bangalore.

Gupta, P. 2019. Maharashtra gets Amul like dairy cooperative with all women team; to sell products under Creyo brand. The Financial Express. DOI: https://www.financialexpress.com/industr y/maharashtra-gets-amul-like-dairycooperative-with-all-women-team-to-sellproducts-under-creyobrand/1796380/(accessed 26.4 .20 )

Jose, E. and Meena, H.R. 2019. Analysis of services rendered to dairy farmers by farmer producer companies. Int J livest res., 9(4):225-229

Elizabeth Jose, H.R. Meena and Verma, A.P. 2019. Case Studies of Dairy Based Farmer Producer Companies in Kerala. Int.J.Curr.Microbiol.App.Sci. 8(1): 501505.

doi: https://doi.org/10.20546/ijcmas.2019. 801.054

Kumar, A. and Parappurathu, S. 2014. Economics of dairy farming and marketing: Microlevel perspectives from three major milk producing states of India. Indian $J$ of Anim Sci., 84(2).204-209

Kumar, A., Mishra, A.K., Parappurathu, S. and Jha, G.K. 2018. Farmers' Choice of Milkmarketing Channels in India. Econ Political Wkly., 53(51): 59

Kujur P, Bharati A and Bhagat U. 2019. Farmer Producer Organization as an Opportunity to Strengthen Small and Marginal Farmers: A Case study in Rajnandgaon District of Chhattisgarh, India. Int.J.Curr.Microbiol.App.Sci. $\quad 8(11)$ : 1832-1838. doi: https://doi.org/10.20546/ijcmas.2019.811. 215

Leitch, H., Ahuja, V., and Jabbar, M. 2014. India's Livestock Sector: Demand Growth, Food Security and Public Investment-Issues and options. Prepared for the World Bank, Washington DC, USA

NABARD. 2015. Farmers' Producer Organisations. Frequently Asked Questions (FAQs). National Bank for Agriculture and Rural Development Mumbai, pp.4-5.

NDDB. 2020. New Generation Cooperatives leading to Producer Companiy DOI : https://www.nddb.coop/services/cooperati ve/newgen (accessed 20.4.20)

Neti, A., Govil, R. and Rao, M.R. 2019.Farmer producer companies in India: Demystifying the numbers, Review of Agrarian Studies, 9(2): 1-11

Paayas, M.P.C. 2019. Annual report, Paayas milk producer company 2018-2019 limited, DOI: http://www.paayasmilk.com/annualreports.php(accessed 20.4.20) 
Pustovoitova, N. 2011. Producer company as an institutional option for small farmers in India.Msc. thesis, $\mathrm{L}$ and University, Sweden, DOI :http://www.lumes.lu.se/sites/lumes.lu.se/f iles/pustovoitova_nadiia_thesis_2011.pdf( accessed 20.4.20).

Rao, S.V.N. 2019. Dairy Cooperatives at the Crossroads? Agricultural Extension South Asia (AESA) Blog 102. DOI: https://www.aesanetwork.org/dairycooperatives-at-the-crossroads/(accessed 20.4.20)

Rao, S.E., Rasheed, V.S., Natchimuthu, K., Ramkumar, S. and Sasidhar, P.V. 2015. Improving the delivery of veterinary services in India. Rev Sci Tech Oie., 34(3):767-777

Satyasai, K.J.S. and Mehrotra, N. 2016. Enhancing farmers' income. Lead paper in foundation day seminar of NABARD, New Delhi :1-27

SFAC. 2013. Policy and Process Guidelines For FPOs, Policy Document Small Farmers Agri-business Consortium, Ministry of Agriculture and Farmers Welfare, Govt. of India available at :http://sfacindia.com/PolicyandProcessGuidelines-for-FPOs.aspx(accessed 20.4.20)

SFAC. 2019. Strategy Paper for promotion of 10,000 Farmer Producer Organizations (FPOs), Small Farmers' Agribusiness Consortium (SFAC), Hauz Khas, New Delhi - 110016

Shah, T. 2016. Farmer Producer Companies. Econ Political Wkly., 51(8):15

Shreeja, M.P.C. 2018. Annual Report, Shreeja mahila milk producer company limited 10-17 available at: https://shreejamilk.com/annualreport/(accessed 24.4.20)

Singh, S. 2019. Producer Company: An Innovative and Enabling Institutional Form for Producer. Owned Enterprises. In Proceedings of 47th Dairy Industry Conference, February 2019. Patna, India. pp.98-99

Singh, M., Chakravarty, R., Bhanotra, A. and Wani, S.A. 2015. Constraints Perceived by the Tribal Dairy Farmers of Ranchi, Jharkhand in Animal Health Care and Management Practices. Indian J Dairy Sci., 68(5):519-21

Singh, S. and Singh, T. 2013. Producer companies in India: a study of organisation and performance. CMA Publication 246 IIM, Ahmedabad, pp.1-115

Sood, J. 2015. New milky way. Down to earth available at https://www.downtoearth.org.in/coverage/ new-milky-way-43368 (accessed 27.04.20)

Sreeram, V., Gupta, J. and Suraj, S.S. 2018. Constraints perceived by dairy farmers of Kerala State. Indian J Dairy Sci., 71(1):102-106

Subburaj, M., Babu, T.R. and Subramonian, B.S. 2015. A study on strengthening the operational efficiency of dairy supply Chain in Tamilnadu, India. Procedia Soc Behav Sci., 89: 285-291.

Trebbin, A. and Hassler, M. 2012. Farmers' producer companies in India: a new concept for collective action? Environ Plan A., 44(2): 411-427.

\section{How to cite this article:}

Devesh Thakur. 2020. Milk Producer Companies in India: A Review. Int.J.Curr.Microbiol.App.Sci. 9(11): 1385-1393. doi: https://doi.org/10.20546/ijcmas.2020.911.163 